\section{MERCURY CONTROL IN THE RTF (U)}

by

\author{
R. A. Malstrom
}

Westinghouse Savannah River Company

Savannah River Site

Aiken, South Carolina 29808

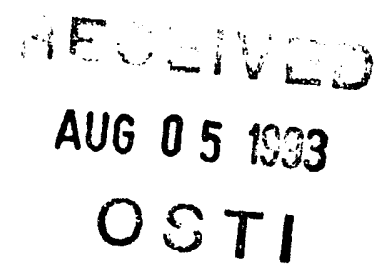

\title{
DISCLAIMER
}

This report was prepared as an account of work sponsored by an agency of the United States Government. Neither the United States Government nor any agency thereof, nor any of their employees, makes any warranty, express or implied, or assumes any legal liability or responsibility for the accuracy, completeness, or usefulness of any information, apparatus, product, or process disclosed, or represents that its use would not infringe privately owned rights. Reference herein to any specific commercial product, process, or service by trade name, trademark, manufacturer, or otherwise does not necessarily constitute or imply its endorsement, recommendation, or favoring by the United States Government or any agency thereof. The views and opinions of authors expressed herein do not necessarily state or reflect those of the United States Government or any agency thereof.

\section{MASTER}

DOE Contract No. DE-AC09-89SR18035

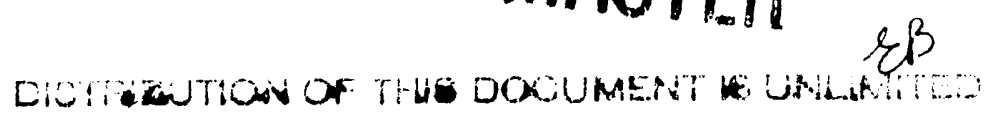

This paper was prepared in connection with work done under the above contract number with the U. S.

Department of Eriergy. By acceptance of this paper, the publisher and/or recipient acknowledges the U. S. Government's right to retain a nonexclusive, royalty-free liceise in and to any copyright covering this paper, along with the right to reproduce and to authorize others to reproduce all or part of the copyrighted paper. 


\section{DISCLAIMER}

This report was prepared as an account of work sponsored by an agency of the United States Government. Neither the United States Government nor any agency thereof, nor any of their employees, makes any warranty, express or implied, or assumes any legal liability or responsibility for the accuracy, completeness, or usefulness of any information, apparatus, product, or process disclosed, or represents that its use would not infringe privately owned rights. Reference herein to any specific commercial product, process, or service by trade name, trademark, manufacturer, or otherwise does not necessarily constitute or imply its endorsement, recommendation, or favoring by the United States Government or any agency thereof. The views and opinions of authors expressed herein do not necessarily state or reflect those of the United States Government or any agency thereof.

This report has been reproduced directly from the best available copy.

Available to DOE and DOE contractors from the Office of Scientific and Technical Information, P. O. Box 62, Oak Ridge, TN 37831; prices available from (615) 576-8401.

Available to the public from the National Technical Information Service, U. S. Department of Commerce, 5285 Port Royal Rd., Springfield, VA 22161. 
Savannah River Technology Center

Westinghouse Savannah River Company

\author{
WSRC-RP-93-441 \\ cc: R.D. Buley, 233-5H \\ T.R. Davis, 233-25H \\ A.S. Horen, 233-31 H \\ R.M. Schroder, 232-H \\ J.R. Dollar \\ R.L. Rabun, 235-H \\ C.E. Coffey, 773-A \\ J.R. Knight \\ T. Motyka \\ L.K. Heung \\ C.W. Jenkins 773-41A
}

keywords: analyzers, 232-H, 233-H

retention: 5 years

March 24, 1993

\title{
MEMORANDUM
}

To: R.J. Alexander, 233-6H

From: R.A. Malstrom, 773-A/36

\section{Mercury Control in the RTF (U)}

\section{SUMMARY}

Engineering controls limit the amount of mercury and moisture introduced to the RTF $(233-\mathrm{H})$. These controls include liquid nitrogen chilled gold traps for mercury and zeolite beds for moisture which are installed in-line. All gas transfers between $232-\mathrm{H}$ or $236-\mathrm{H}$ to 233-H will pass through these traps. Barring unforeseen catastrophic failure of the traps, no detectable amounts of mercury will be introduced via this route. However, a small amount of mercury (near Technical Review:

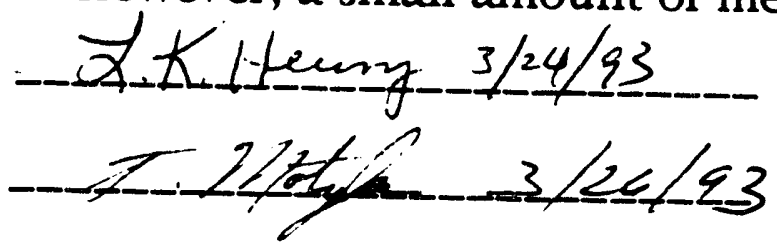


detection limits) will be introduced via the reservoir recycle stream. This amount is conservatively calculated to be 7 milligrams per year and will have negligible impact on hydride bed performance. In no case will the design agency limits for mercury $(0.3 \mu \mathrm{g} / \mathrm{liter})$ be approached, because the reservoir recycle gas is much lower than those limits already, and the hydride beds will amalgamate with any free mercury.

\section{DISCUSSION}

The Replacement Tritium Facility was designed so all gas transfers from $232-\mathrm{H}$ and $236-\mathrm{H}$ would have to pass through zeolite beds to remove moisture and liquid nitrogen chilled gold traps to remove mercury. The transfer lines are interlocked with normally-closed valves which shut when the gold traps warm to -75 degrees Celsius. The vapor pressure of mercury at -75 degrees is below detection limits.

The only other way for mercury to enter $233-\mathrm{H}$ would be through the reservoir recycle stream. Reservoirs filled in $234-\mathrm{H}$ will be unloaded in 233-H and small amounts of mercury will be introduced via this route. However, this will not cause any problems because the $234-\mathrm{H}$ process was designed to minimize the amount of mercury loaded in reservoirs. All gas passes through chilled gold traps which remove mercury to 15 times less $(.02 \mu \mathrm{g} /$ liter) than the design agency requirements. In addition, mercury vapor tests are performed each month, and after each rupture disk failure, to check for mercury which might be introduced via the rupture disk header.

The primary separator is the first hydride bed exposed to the gas, and it is the bed where any mercury from the recycled reservoirs will first amalgamate. It contains 30 kilograms of palladium coated on kieselguhr. It is estimated that only 7 milligrams of mercury would be introduced each year. Forty years of operation would add less than 0.5 grams of mercury'. Comparing this number to the 30 kilograms of palladium, it is clearly insignificant. Experiments have shown that the bed's performance will not be compromised by this amount of amalgamation. 1 Heating the primary separator bed will cause some of the amalgamated mercury to desorb and be amalgamated by subsequent hydride beds. However, this small

\footnotetext{
${ }_{1}$ M.S. Ortman, T.J. Warren and D.J. Smith, "Use of Metal Hydrides for Handling Tritium," Eusion Technelogy \& 2330 (1985).
} 

amount of mercury will not cause any problems with any of the
hydride beds.

The initial reservoir recycle gas is below design agency limits for mercury, and the gas is stored on several hydride beds as it passes through the $233-\mathrm{H}$ process. Each of these beds will amalgamate with any free mercury. Therefore, the gas loaded from $233-\mathrm{H}$ will have negligible amounts of mercury, and be well below design agency

Finally, analyzers will be used to check the mix tank piping and compressor feed lines for possible mercury contamination. These tests will be performed on a regular basis (initially after each transfer with a limit of at least quarterly). Any mercury contamination would be discovered at this location before it would be seen at the loading lines, whether it came from the transfer lines
or recycle stream. 

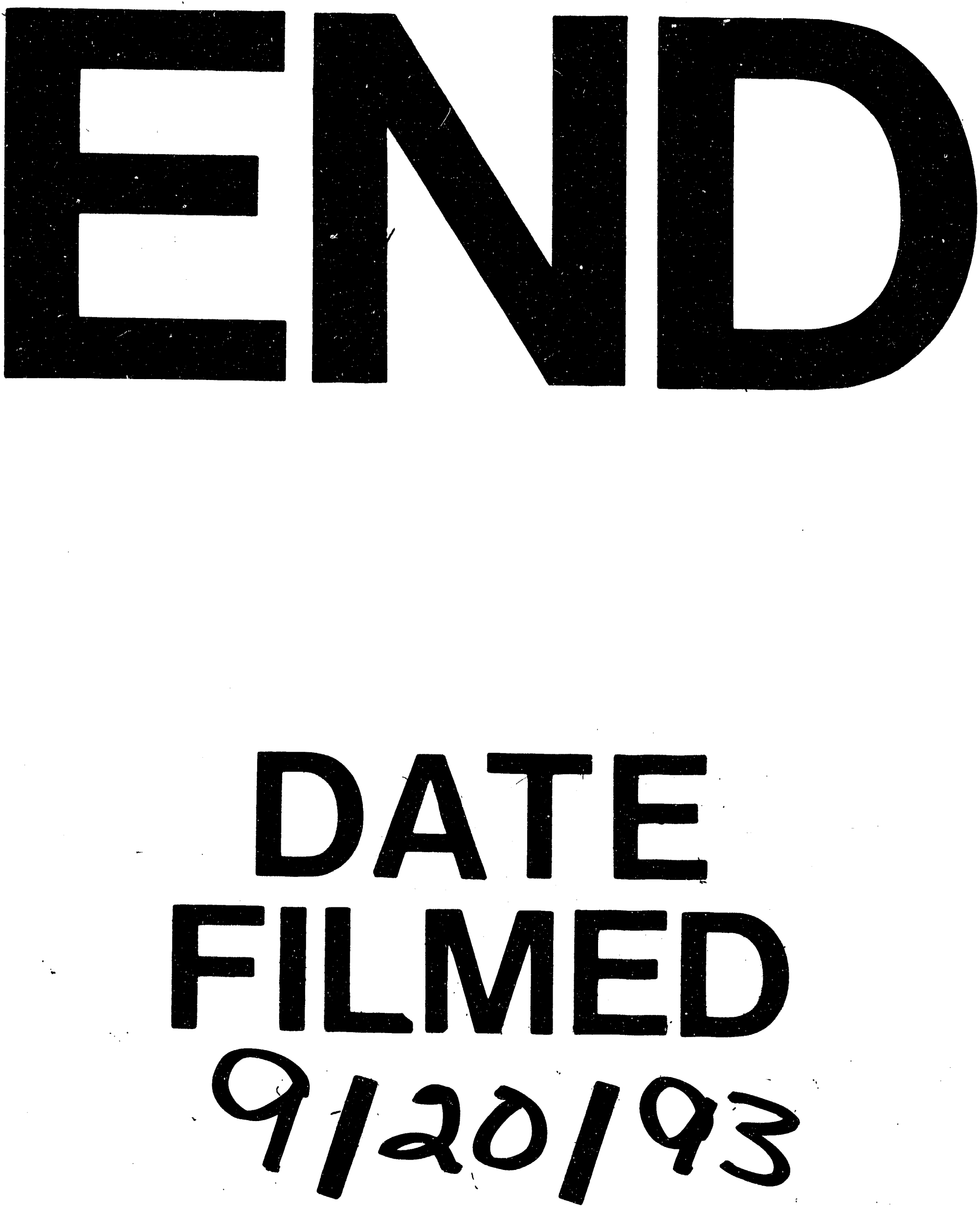
